\title{
Diversity Kikuyu grass (Cenchrus clandestinus): A review
}

\section{Diversidad del pasto Kikuyo (Cenchrus clandestinus): Una revisión}

\author{
Juliana Arango-Gaviria ${ }^{1 *}$, Julian Echeverri-Zuluaga ${ }^{2}$, Albeiro López-Herrera $^{3}$ \\ I*Masters in Biotechnology, jarangog@unal.edu.co, ORCID: 0000-0002-4623-4588, Universidad Nacional de Colombia, Medellin, Colombia. \\ 2PhD in Animal Sciences, jjecheve@unal.edu.co, ORCID: 0000-0002-4623-4588, Universidad Nacional de Colombia, Medellin, Colombia. \\ ${ }^{3}$ Doctor in Basic Biomedical Sciences, alherrera@unal.edu.co, ORCID: 0000-0003-1444-3470, Universidad Nacional de Colombia, Medellin, Colombia.
}

How to cite: J. Arango-Gaviria, J. Echeverri-Zuluaga y A. Lopez-Herrera, "Diversity Kikuyu grass (Cenchrus clandestinus): A review”. Respuestas, vol. 24, no. 2, pp. 81-88, 2019.

Received on September 25, 2018; Approved on December 15, 2018

\begin{tabular}{ll}
\hline ABSTRACT \\
\hline Keywords: & $\begin{array}{l}\text { Kikuyu is a perennial plant of rapid growth and high aggressiveness, which represents one of the most } \\
\text { important resources for the development of the economy and to support specialized livestock in Colombia. }\end{array}$ \\
$\begin{array}{l}\text { Poaceae, } \\
\text { Genetic variability, }\end{array}$ & $\begin{array}{l}\text { It was introduced in the mid-30s, where it has spread thanks to its invasive nature; However studies have } \\
\text { been conducted, few have focused on genetic diversity and phenotypic variability within populations, as } \\
\text { variation. }\end{array}$ \\
& $\begin{array}{l}\text { well as possible contributions that they can provide sustainability to the agricultural sector. The objective of } \\
\text { this review is to explore prior information about some basic topics of this forage species and especially on its } \\
\text { diversity and genetic variability at different latitudes. A systematic search was conducted scientific articles, } \\
\text { indexed journals, books and documents that had as main axis basic information about topics mainly on grass } \\
\text { and variability and genetic diversity. In other countries they have been registered several lines of Kikuyu } \\
\text { grass, as well as some studies on genetic diversity that have been determined in different populations, large } \\
\text { amount of genetic variation consistent with the morphological diversity that has grass. }\end{array}$
\end{tabular}

\section{RESUMEN}

\section{Palabras clave:}

Poaceae,

Variabilidad genética,

Variación fenotípica.
El kikuyo es una planta perenne de rápido crecimiento y alta agresividad, la cual representa uno de los recursos más importantes para el desarrollo de la economía y para el soporte de la ganadería especializada en Colombia. Fue introducido a mediados de los años 30, donde se ha propagado gracias a su carácter invasivo; sin embargo de los estudios que se han realizado, pocos se han centrado en la diversidad genética y variabilidad fenotípica dentro de sus poblaciones, así como las posibles contribuciones que estas puedan proveer a la sustentabilidad al sector agropecuario. El objetivo de esta revisión es explorar información previa acerca de algunos tópicos básicos de esta especie forrajera y principalmente sobre su diversidad y variabilidad genética en diversas latitudes. Se realizó una búsqueda sistemática de artículos científicos, revistas indexadas, libros y documentos que tuvieran como eje principal información acerca de tópicos básicos del pasto y principalmente sobre la variabilidad y diversidad genética. En otros países han sido registradas varias líneas de pasto kikuyo, así como también, algunos estudios sobre diversidad genética que han logrado determinar en diferentes poblaciones, gran cantidad de variación genética consistente con la amplia variabilidad morfológica que tiene pasto.

\section{Introduction}

For decades in cold climates of Colombia and many other parts of the world, pennisetums (Originally named Pennisetum clandestinum Hoechst. Ex Chiov) It has been considered one of the most important

*Corresponding author.

E-mail address: jarangog@unal.edu.co (Juliana Arango Gaviria)

(c) $\Theta \Theta$ Peer review is the responsibility of the Universidad Francisco de Paula Santander.

This is an article under the license CC BY-ND (http://creativecommons.org/licenses/by-nc-nd/4.0/).

It has been considered one of the most importantgrasses in feeding dairy cattle specialist. [1] - [4].

Features such as resistance to trampling, aggressive growth habit and efficient response to fertilization [5]- [9]. 
They transformed it into an important factor in productivity and economy of the dairy chain. For this reason pastures and especially the Kikuyu grass represent an important resource for the development of the economy and the support of livestock [10] - [12]. Despite these attributes and their extensive agronomic and zootechnical knowledge, few studies exist at the genetic level of this resource meaningful.

Studies on diversity and genetic variability of agricultural resources are of vital importance not only for the conservation and evolutionary genetics but also for future studies based on sustainability and agricultural productivity. Determining the variability of the kikuyu grass, could allow access to a wide range of options in terms of advantages and qualities that can offer different varieties. Therefore, the aim of this work is to gather prior information about some basic topics of this forage species and especially on its diversity and genetic variability at different latitudes.

\section{Materials and methods}

To carry out this review, an analysis of existing information made on general studies, phenotypic variability and genetics of the kikuyu grass. The review was based on the search for scientific articles indexed journals, books and documents that had as main focus historical information about some basic topics mainly on grass and variability and genetic diversity of this in different parts of the world. This document gives great importance to research conducted by national and international researchers who have contributed to the knowledge of this species.

\section{Results and Discussion}

\section{Botanical description}

Kikuyu is a perennial rhizomes rapid growth and high aggressiveness that spans stolons and [13] - [16]. Its leaves are usually narrow and longup to $25 \mathrm{~cm}$ and $2.5 \mathrm{~mm}$ wide, glabrous or can be provided with hairs subtle,its ligule pale greenish, commonly has dense fine hairs $2 \mathrm{~mm}$ long. The stems are branched and can reach a size of $60 \mathrm{~cm}$, which are provided with cylindrical entrenudos fistulous glabrous nature and knots that can strongly root [17] - [19]. The inflorescence is 1-4 spikelets of about $10-20 \mathrm{~mm}$ long growing in the axils of leaves and pods are hidden(Hence the name of the clandestinus species). Stamen and stigma are exserted, may possess anthers 5-7 $\mathrm{mm}$ long and one $30 \mathrm{~mm}$ stigma. Structures like glume and palea lower are absent, the top and bottom slogans are approximately 19-22 cm long. Each spikelet has two flowers: fertile stand in which the filaments and a bottom which is sterile [19] [21].

\section{Nomenclature}

French botanist Andreas Schimper collected from an unknown location Africa the first specimen; which he was described in 1903 by botanist Emilio Chiovenda, Based on the name "kikuyu" assigned previously by Christian Ferdinand Friedrich Hochstetter. The Royal Botanic Gardens Kew England received samples for the first time in 1906, but because of their quality they mistook for a while with Pennisetum Pennisetum longistylum and then longistylum var. clandestinum until well described and published under the scientific name "Pennisetum clandestinum Hochst. ex Chiov. 1921" [22].

Recently [23] They evaluated by phylogenetic and morphological studies, the validity of traditional taxonomic divisions of the genera Pennisetum and Cenchrus; the differences between sections of these are often weak [24], so some studies have proposed the inclusion of Cenchrus within Pennisetum. The results presented by this team supported the unification in some specimens, including naming change the pennisetums to Cenchrus clandestinus.

History and geographical distribution worldwide 
The Kikuyu grass is native highlands of East and Central Africa (Ethiopia, Kenya, Uganda, Tanzania, Rwand, Zaire and Congo) characterized by habitats low temperatures, high humidity, and areas elevated heights between 1950 and $2700 \mathrm{~m}$ approximately. Because of its invasive and high levels of fertility character was introduced to different countries in order to improve pastures for feed for livestock [5], [25] - [27]. Travelers and natives in Africa recognize these qualities and impressed by his vigor made the introduction of this species in several foreign countries and the continent; an example of this occurred in 1910, when Forbes moved to Pretoria Botanical Gardens, stolons collected on the shores of the lakeNaivasha, One of the highest places in eastern Kenya, Becoming the vegetative material that would be the basis of all kikuyu pastures distributed by South Africa [22], [28].

In the year 1919 the kikuyo was introduced into Australia from seeds obtained from the Congo, of which all but one, germinated in the Botanical Garden of Sydney [22], [29]. This material was cut and distributed statewide by the first agricultural school in New South Wales South Australia; "Hawkesbury Agricultural College" in 1920, and spread to the states of Queensland, Victoria, Australia to the south, west, and countries like New Zealand and Fiji[25], [29]. He later settled on the side of the east coast of Australia, where large amounts of dairy farms were concentrated. During this time was also introduced in countries near the equator with characteristics of mountainous climates regions humid subtropical and also in many other countries where their performance showed promise as Nigeria, Cameroon, Brazil, Paraguay, Costa Rica, Colombia, Panama, Hawaii, Taiwan, Madagascar, Angola etc. [22], [25], [30], [31].

Because of its establishment at international level, its invasive nature and its productive potential; the kikuyo now has developed a wide geographic range comprising ecologically suitable upland areas.

Colombia was introduced in the mid-30s, which it has spread due to its invasive nature for almost all pastures and fertile fields, Displacing most of forages and weeds growing in cold climates. Prior to its introduction, mountain pastures were mostly dominated by grasses forming tillers and not forming lawn by rhizomes, like kikuyu.

\section{Reproduction}

The most common method of setting the pennisetums is asexual reproduction by vegetative propagation of stolons vigorous and adventitious roots that appear in each node; this plant surface extends through thick rhizomes that can reach one meter in length [17], [32] - [34]. Cutting these stolons leads to secondary and sometimes formed short stems carrying terminal pins [5], [30], [35]. However, disputes have been reported on the possible existence of apomixis, where the mother plant produces seeds without fertilization to occur, generating an individual genetically equal to it [22], [28].

On the other hand a common feature in the mode of sexual reproduction in the grass family, is the existence of hermaphrodite plants that are pollinated by the wind, taxonomists in pennisetums have determined the existence of hermaphrodite individuals and men who are infertile [29], [35].

The fertile kikuyo has filaments that can measure up to $40 \mathrm{~mm}$, capable of releasing depending on the strength of the wind to 2500 pollen grains [36]. The male individuals (Figure 1A) sterile, considered the most aggressive nature, they are recognized by a functional stigma predominates to $15 \mathrm{~mm}$ in length and by the absence of stamen filaments and flowers; Plants with these characteristics were described until 1930 in Australia, favoring the hypothesis that this kikuyo was originally introduced from Africa [37]. There are conflicting opinions on whether this 


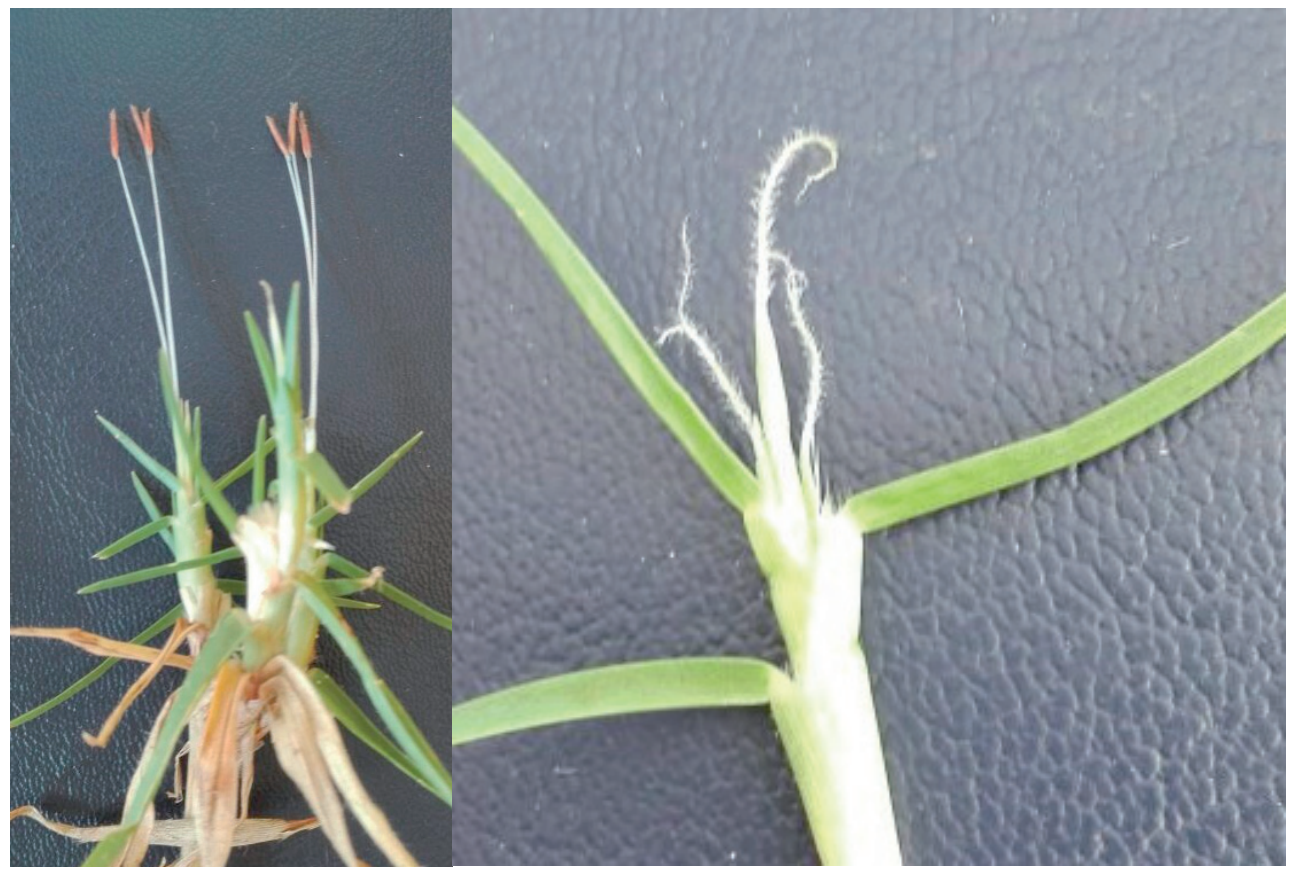

Figure 1. A) Flor male Cenchrus clandestinus B) Pistil Cenchrus clandestinus Source: authors

condition is due to a dominant character [38].

Bloom the usually grass go unnoticed by nature discrete and inconspicuous inflorescence in both male structures and female (Figure 1B), the which are hidden between the sheaths and are composed of numerous short spikes which can easily be overlooked [5], [20]. In addition, the requirement of rapid growth to generate enough dry matter has made early flowering was lost in paddocks for high production[36].

In equatorial regions is unlikely that environmental factors such as the duration of the day or temperature influence flowering, so some authors have suggested by control of apical dominance and the presence of auxin that the deleted [28]. Carr and Eng (1956) Found that defoliation promoted continuous flowering Kikuyugrass concluding that these substances, being contained in the tip of the growing stolons undefoliated the suppressed.

\section{Phenotypic variability of the pennisetums}

Some studies have been made of the kikuyu grass, few have focused on the variability within populations; one reason is the low phenotypic variation between varieties, making it difficult to distinguish the high level of plasticity has the grass; however they have been sufficient to determine the presence in some countries called cultivars or ecotypes of the kikuyu [19], [36]. The presence of marginal or different climatic conditions that separate regions of their natural habitat, areas foster an environment for the development of these ecotypes [22].

Edwards was the first to examine and recognize three ecotypes into six ecological areas in eastern Africa (Molo, plateaus Kinankop, Mount Kenya, Mount Elgon, Kericho and Upper Gilgil), where primarily the differences focused on morphology leaf and flowering behavior [29]. In the middle of the year 1930 named as Kabete, Molo and Rongai, based on the area where they were collected.

The author reported differences in various characteristics, for example Rongai was characterized by leaves and stems of thick and wide body, however, in Molo were thin and narrow while Kabete presenting intermediate size. As for the color of the fodder Rongai was dark green contrary to the Molo and Kabete were light green. In bloom different behavior was also discovered in the flowering ecotype Kabete generated 24 hours after cutting the outbreak stigmas 5 days after in Molo demonstrating 
less anthers, while the Rongai not generated [36]. As mentioned above, the bloom is controlled by apical dominance and eliminating auxin with constant defoliation of stolons, but the views each ecotype vary sensitivity to these components. The Whittet variety seems to flourish easily because it is less sensitive to auxin; In contrast to other the Flower does not appear in pastures and apical growth is dominant [28], [39], [40].

\section{Kikuyu grass lines recognized}

In Australia have been recorded several lines of kikuyu grass in the Whittet, Crofts, Noonan and cultivars included Breakwell [19], [36], [41]. Seed farming Breakwell was collected from fertile kikuyo area in 1965 and registered in 1971 by the Agricultural Experiment Station Grafton (Most of these individuals are fertile females but $15-20 \%$ are male sterile); features such as finer leaves and narrow, short internodes, short stems, dense grass and thin, did ideal for erosion control and residential use. In contrast to cultivate Whittet, registered in 1970 appeared to be thicker, with larger leaves, longer internodes and the apparently containing more crude protein than common kikuyo .In open pollination of these two lines was obtained "Noonan "fertile cultivar, morphologically similar moreWhittet, showing better performance of dry matter in the winter time. Finally the cultivar "Crofts" with a slim appearance and vertical blades, was recorded in 1983, and selected by producing viable seeds grazing and resistance to cold [19], [42]. In Hawaii, they have also reported the existence of these and other cultivars developed in theExperimental station Agriculture is like the case of "Hosaka" [5].

\section{Studies of genetic and phenotypic variability}

Genetic diversity is the variation of genes within species, encompassing diversity within the same population or genetic variation among populations. Genetic differences naturally occurring between organisms within species are demonstrated by genetic polymorphisms, which accumulate until the diversity within each species occurs, what is called genetic divergence [43], [44].
The first study of genetic diversity was performed kikuyo Wilen et to the (1995) by isoenzyme analysis and gel electrophoresis starch; in order to predict the invasive and aggressive potential golf courses in California. Results in 12 genotypes were identified, however it was concluded that genetic diversity was low due to high similarities in the subpopulations.

They were also implemented marker techniques RAPD (Random Amplified Polymorphic DNA) for determining genetic variation in kikuyo lines. Morris (2009)I use this methodology and determine that achievement lot of genetic variation found in different populations it was consistent with the morphological diversity of the grass. In the study 13 primers were used with reproducible bands (Selected from previous research conducted in Cynodon spp); which they generated 195 markers of which $98.85 \%$ were polymorphic. Among the results was that the lines"Noonan" and "Breakwell" in Australia were closely related (82\%), while "Crofts" and "Whittet" although they were in the same group had only $56 \%$ similarity.

Phenotypic variation was significant, of the analysis DE16 ecotypes two lines, the first were identified with a leaf width over $18 \%$ than the average and the second with a width analysis stolon $15 \%$ thicker than the average. Lowe et to the (2010)Investigated the phenotypic and genetic variation within natural populations, cultivars and mutagenic populations in many parts of Australia, showing significant differences in performance of the forage plant height, detergent fiber neutral, acid detergent fiber, crude protein and digestibility in vitro dry matter. Genotypic variation was performed using amplified DNA fingerprinting (DAF), showing the presence of two groups classified as kikuyu "common" and cultivars Whittet, Noonan and Crofts [45]. recently technologies as DArTseq have generated SNP (Single Nucleotide Polymorphism) for evaluation of accessions of Hawaii, California and Australia which showed variation among germplasm sources, concluding that these accessions were important repositories for diversity as they found that Australia and Hawaii had a much wider range of genetic variation that accessions California [46]. 
Additionally, other authors have explored the phylogenetic relationship within the family Poaceae, using markers chloroplast ( $\mathrm{rpoC} 2$, matK and $\mathrm{rbcL}$ ) of a number of grasses including among them the kikuyo, which have been useful for investigating various topics such as variation of speciation and morphological and ecological diversification of important crops [47], [48].

\section{Conclusion}

Most production systems in the country are based on rotational grazing where the Kikuyu grass is the basis of the forage supply. Consequently, researchers and producers have focused primarily on the study of the chemical and nutritional composition, despite its great attributesand its extensive agronomic and zootechnical knowledge few studies that exist at the genetic levelLeaving aside the knowledge of their diversity which establish particular characteristics of each of its varieties could.

As the most common and known propagation method is the kikuyo through the vegetative form and also a high level of plasticity is observed; the formation of clonal populations in the prairies would be expected, but sexual reproduction through seeds and various dispersion media such as wind and cattle droppings in constant motion [36]; They represent a great opportunity for variants and diversity of genotypes because of the wide range of environmental conditions under which the kikuyu grass grows generated.

\section{Acknowledgment}

We thank the Universidad Nacional de Colombia at Medellín (Project "Development of microsatellite markers and cytogenetic analysis of Kikuyu grass (Cenchrus clandestinus) in the department of Antioquia" No 44330).

\section{References}

[1] A. Morales, J. Leon, E. Cardenas, G. Afanador and J. Carulla, "Chemical composition of milk, in vitro digestibility solids and production in cows fed grasses solas o associated with Lotus uliginosus", Revista de la Facultad de
Medicina Veterinaria y de Zootecnia, vol. 60, no. 1, pp. 32-48, 2013.

[2] J. E. Mojica, J. Castro, E. Cardenas, M. Pabon and J. Carulla, "Effect of the offer of kikuyu grass (Pennisetum clandestinum) on production and bovine milk quality composition", Livestock Research for Rural Development, vol. 21, no. 1 pp. 1-11, 2009.

[3] B A. taborda, R. Ochoa-Ochoa and M. Medina-saw, "Effect of different doses of compound fertilizer on the quality of kikuyu grass (Pennisetum clandestinum Hochst. Ex Chiov.)", Pastos y Forrajes, vol. 37, p. 31-37, 2014.

[4] FEDEGAN, "Analysis of the 2014 Colombian Livestock Inventory, Behavior and explanatory variables," $2014.2 \mathrm{http}$ :// www.fedegan.org.co/publicacionpresentaciones/analisis-del-inventarioganadero-colombiano-comportamiento-yvariables.

[5] G. Fukumoto and C. Lee, "Kikuyu grass for forage", University of Hawaii, 2003.

[6] A. Prieto and G. Sanchez, "Evolution of the botanical composition of meadow kikuyo (Pennisetum clandestinum) recovered by mechanical scarification and fertilization compost", Revista Corpoica, vol. 5, pp. 70-75, 2004.

[7] J. Echeverri-Zuluaga, L. Restrepo-Betancur and J. Parra-Suescún, "Benchmarking productive and agronomic parameters of kikuyu grass Pennisetum kikuyu under two fertilization methods", Revista Lasallista de Investigación, vol. 7, no. 2, pp. 94-100, 2010.

[8] Y. Urban, I. Arriojas and C. Davila, "Effect of fertilization in association Kikuyugrass -alfalfa (Pennisetum clandestinum-Medicago sativa) protein and digestibility 2.Content", Zootecnia Tropical, vol. 13, no. 2, pp. 183-198, 1995.

[9] C. Wilen and J. Holt, "Spatial Growth of Kikuyugrass (Pennisetum clandestinum)", 
Weed Science Society of America, vol. 44, no. 2, pp. 323-330, 1996.

[10] J. Leon, J. Mojica, E. Castro, E. Cardenas and M. Pabón, "Nitrogen and phosphorus balance of cows offered Preferred Amounts of different kikuyu (Pennisetum clandestinum) and Supplemented With oats (Avena sativa) silage", Revista Colombiana de Ciencias Pecuarias, vol. 21, pp. 559-570, 2008.

[11] J. Apraez, O. Benavides and I. Guzman, "Response of the pennisetums (Pennisetum clandestinum, hoechtst) at different levels of nitrogen fertilization organic and/or mineral", Journal of Agricultural Sciences, vol. 16, no. 1-2, 1999.

[12] H. Correa, R. Pabón and J. Carulla, "NoNutritional value of kikuyu grass (Pennisetum clandestinum Hoechst Chiov Ex.) For milk production in Colombia: A review. I- Chemical composition, ruminal digestibility and postruminal", Livestock Research for Rural Development, vol. 20, no. 4, pp. 1-41, 2008.

[13] S. C. Miyasaka, JD Hansen and GK Fukumoto, "Resistance to yellow sugarcane aphid: Screening Kikuyu and other grasses", Crop Protection, vol. 26, no. 4, pp. 503-510, 2007.

[14] P. Skerman and F. Riveros, "tropical grasses. Rome", Food \& Agriculture Org, 1990.

[15] C. Wilen et al., "Genotypic diversity of Kikuyugrass (Pennisetum clandestinum) Populations in California Published by: Weed Science Society of America and Allen Press Stable Linked", Weed Science Society of America, vol. 43, no. 2, pp. 209-214, 1995.

[16] E. Insuasty, J. Apraez and J. Navia, "Effect of the arrangement silvopastoril Alnus acuminata (K.) and kikuyo (Pennisetum clandestinum H.) on the productive performance in Holstein heifers in highland Nariño", Agroforestry Neotropical, vol. 1, pp. 1-8, 2011.

[17] B. A. Muscolo, M. Panuccio and A. Eshel, "ecophysiology of Pennisetum kikuyu: A valuable salt tolerant grass", Environmental and Experimental Botany, vol. 92, pp. 55-63, 2013.

[18] M. Wolf and Sanchez, "agrostology, 1st ed", Costa Rica, 2001.

[19] G. Cook et al.,'Tropical Forages: an interactive tool selection", 2005.

[20] J. Leon, "Botanica tropical crops", 3rd ed. San Jose, Costa Rica, 2000.

[21] L. Bernal, "Pastures and tropical forages: production and management", 3rd ed. Bogotá, Colombia, Banco Ganadero, 1994.

[22] T. Mears, "Kikuyu-(Pennisetum clandestinum) as a pasture grass-a review", Tropical Grasslands, vol. 4, no. 2, pp. 139-152, 1970.

[23] M. Chemisquy, L. Giussani, M. Scataglini, E. Kellogg and O. Morrone, "Phylogenetic studies the unification of Favor Pennisetum, Cenchrus and Odontelytrum (Poaceae): A combined nuclear, plastid and morphological analysis, and nomenclature in Cenchrus combinations", Annals of Botany Oxford, vol. 106, no. 1, pp. 107-130, 2010.

[24] J. Wipff, "nomenclatural CHANGES IN PENNISETUM (Poaceae: Paniceae)", AIDS Contribution to Botanic, vol. 19, no. 3, pp. 523-530, 2001.

[25] S. Garcia, M. Islam, C. Clark and P. Martin, "Kikuyu-based pasture for dairy production: A review", Crop and Pasture Science, vol. 65, no. 8, pp. 787-797, 2014.

[26] W. Hanna, C. Chaparro, B. Mathews, J. Burns, L. Sollenberger and J. Carpenter, "Perennial Pennisetums", Warm-season (C4) grasses, no. february, pp. 503-535, 2004.

[27] C. Wilen, D. Cudney, C. Elmore and V. Gibeault, "Kikuyugrass Integrated Pest Management for Home Gardeners and Landscape Professionals", UC Statewide Integrated Pest Management Program University of California, 2011. 
[28] J. Marais, "Factors Affecting the nutritive value of kikuyu grass (Pennisetum clandestinum) -a review", Tropical Grasslands, vol. 35, pp. 65-84, 2001.

[29] C. Bourke, "A review of kikuyu grass (Pennisetum clandestinum) in cattle poisoning", Australian Veterinary Journal, vol. 85, no. 7, pp. 261-267, 2007.

[30] Ecocrop Database, "Food and Agriculture Organization of the UN (FAO)", 2010. http://ecocrop.fao.org/ecocrop/srv/en/ cropSearchForm.

[31] CABI, "Invasive Species Compendium", The Association of International Research and Development Centers for Agriculture, 2015. https://www.cabi.org/isc/datasheet/39765.

[32] D. Gade, "Plants, Man and the Land in the Vilcanota Valley of Peru", 1975.

[33] J. Gross, "CARE GOLF COURSE Looking at Kikuyugrass Kindly", Stover seed, no. august, 2003.

[34] C. Soto and A. Valencia, "Effect of cutting age and the level of nitrogen fertilization on energy and protein value of the kikuyu grass", Revista Colombiana de Ciencias Pecuarias, vol. 181, no. 33, pp. 17-26, 2005.

[35] V. Youngner, W. Wright and E. Zimmerman, "Kikuyugrass-its management and control", California Turfgrass Culture, vol. 21, no. 1, pp. 1-8, 1971.

[36] B. Morris, "Variation and Breeding of Kikuyu Grass (Pennisetum clandestinum)", University of Sydney, 2009.

[37] D. Parker, "Strain variation and seed production in kikuyu gras (Pennisetum clandestinum Hochst.)", Journal of the Deptartment of Agriculture of South Australia, vol. 45, pp. 55-59, 1941.

[38] G. Piggot and H. Morgan, "A genetic basis for male sterility in kikuyu grass", Tropical Grasslands, vol. 20, pp. 34-36, 1986.
[39] K. Carr and D. Eng, "Experimental induction of flower formation in kikuyu grass (Pennisetum clandestinum Hochst. Ex chiov.)", Australian Journal of Agricultural Research, vol. 7, no. 1, pp. 1-6, 1956.

[40] D. Loch and J. Ferguson, "Forage Seed Production Tropical and subtropical species", 1999.

[41] K. Lowe, T. Bowdler, K. Sinclair, T. Holton and S. Skabo, "Phenotypic genotypic variation and Within Populations of kikuyu (Pennisetum clandestinum) in Australia", Tropical Grasslands, vol. 44, no. 2, pp. 84-94, 2010.

[42] I. Partridge, "Better Pastures for the tropics and subtropics", Tropical Grassland Society of Australia Inc., 2011. [Online]. Available: www.tropicalgrasslands.asn.au/pastures/ kikuyu. html.

[43] D. Dominguez and V. Dominguez, "Phylogeography: taxonomy and conservation applications O. Dominguez - Domínguez \& E. Vazquez - Dominguez", Animal biodiversity and conservation, vol. 1, no. 1, pp. 59-70, 2009.

[44] F. Molina-Freaner, T. Markow, S. Diego, O. Rojas-Soto and A. Varela-rosemary, "genetic diversity", Mora-Cantu, 2010.

[45] T. Holton, S. Skabo, K. Lowe and K. Fsinclair, "Genetic fingerprinting of Natural Populations kikuyu in Australia", Tropical Grasslands, vol. 41, no. 3, pp. 236-237, 2007.

[46] J. Mock, "Management and Genetic Variability of Kikuyugrass (Pennisetum clandestinum Hochst. Ex Chiov.)", University of California, 2016.

[47] S. Aliscioni et al., "New grass phylogeny Resolves deep evolutionary relationships and discovers C 4 origins", New Phytologist, vol. 193, no. 2, pp. 304-312, 2012.

[48] R. Duvall, D. Noll and H. Minn, "phylogenetics of Paniceae (Poaceae)", American Journal of Botany, vol. 88, no. 11, pp. 1988-1992, 2001. 